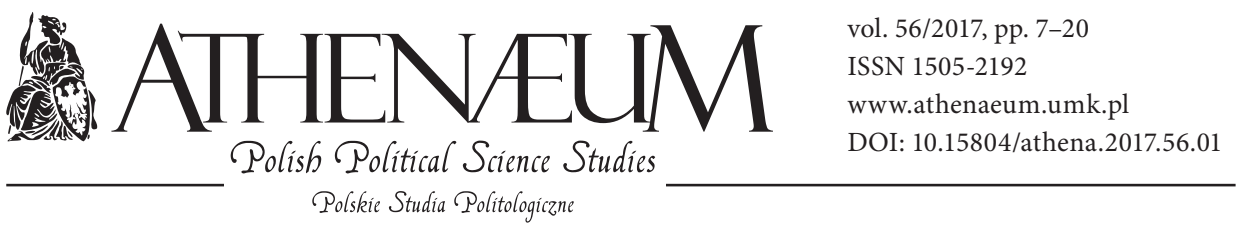

\title{
POLISH GEOPOLITICAL CODES ILLUSTRATED WITH THE EXAMPLE OF THE ELECTORAL PROGRAMS OF THE MAJOR POLITICAL PARTIES IN 1991-2011
}

\author{
POLSKIE KODY GEOPOLITYCZNE NA PRZYKŁADZIE \\ PROGRAMÓW WYBORCZYCH NAJWAŻNIEJSZYCH PARTII \\ POLITYCZNYCH W LATACH 1991-2011
}

Jarosław Macała*

\begin{abstract}
This article is concerned with the research on Polish geopolitical codes following 1989. The problem has not yet been the subject of broader scientific studies or publications. In this aspect, the research is of particular importance for the analysis of foreign policy of Poland, which had to redefine its place in Europe and to fundamentally rebuild external relations, that is also to define the new geopolitical codes. The code system used in this text is based on Colin Flint's definition, with the key division into allies and enemies. Based on the analysis of discourse, it can be stated that the most important allies of Poland in these codes are the USA, the European Union, Germany, and the enemy is Russia. In general, the fundamental change of Poland's geopolitical codes following 1989 - from the east side to the west - can quite easily be seen in the electoral programs: the enemies of the People's Republic of Poland's
\end{abstract}

Artykuł dotyczy badań nad polskimi kodami geopolitycznymi po 1989 r. Problem ten nie doczekał się na razie szerszych studiów naukowych ani publikacji. W tym aspekcie badania mają szczególne znaczenie dla analizy polityki zagranicznej Polski, która musiała na nowo określić swoje miejsce w Europie i gruntownie przebudować relacje zewnętrzne, czyli także zdefiniować nowe kody geopolityczne. Systematyka kodów zastosowana w niniejszym tekście opiera się na definicji Colina Flinta, z kluczowym podziałem na sojuszników i wrogów. W oparciu o analizę dyskursu można stwierdzić, iż najważniejszymi sojusznikami Polski w tych kodach są USA, Unia Europejska, Niemcy, wrogiem zaś Rosja. Na ogół dosyć czytelnie widać w programach wyborczych zasadniczą zmianę kodów geopolitycznych Polski po 1989 r. ze wschodniej na zachodnią: wrogowie z okresu Polskiej Rzeczypospolitej Ludowej

* University of Zielona Góra, Institute of Political Science. 
period became allies, and the forced ally became an enemy. However, their concretization is generally not original and rather schematic. The Polish geopolitical codes have been exerted with strong influences of the hegemonic geopolitical codes of the West, mainly those of the United States. On the other hand, the last geopolitical code, the attempt to explain to the public the geopolitical imaginations of our elites, has been the weakest. This largely confirms the authoritarian dimension of Polish top-down transformation as well as the dominance of the elites over the society.

Keywords: geopolitics, critical geopolitics, Polish geopolitical codes, Polish political parties, election programs zostali sojusznikami, a przymusowy sojusznik został wrogiem. Jednak ich konkretyzacja jest na ogół mało oryginalna i schematyczna. $\mathrm{Na}$ polskich kodach geopolitycznych odciskały się wyraźnie silne wpływy hegemonicznych kodów geopolitycznych państw Zachodu, głównie USA. Natomiast najsłabiej obecny był ostatni kod geopolityczny, czyli próba wytłumaczenia wyobrażeń geopolitycznych naszych elit opinii publicznej. W dużej mierze potwierdza to autorytarny wymiar polskiej, „odgórnej” transformacji, a także dominację elit nad społeczeństwem.

Słowa kluczowe: geopolityka, geopolityka krytyczna, polskie kody geopolityczne, polskie partie polityczne, programy wyborcze

\section{INTRODUCTION}

The school of critical geopolitics and the related geopolitical codes issues are little known and underappreciated among our researchers. It is visible in the small number of publications. Undoubtedly, it is the multidisciplinary and interdisciplinary field of research, particularly challenging in terms of methodological terms. Even more so: the scientific penetration of geopolitical codes refers to ambiguous methods related to discourse analysis.

In my opinion, the problem of Polish geopolitical codes, especially in the $20^{\text {th }}$ century, due to its cognitive values, extensive and diverse source database, but also due to the complex matter should be the subject of individual and team research of scientists from different disciplines. In this aspect, the research is of particular importance for the analysis of the Third Republic of Poland's foreign policy, which had to redefine its place in Europe and to fundamentally rebuild external relations, that is also to define new geopolitical codes (Zięba, 2012). Such reflections and their practical implementation are generally the work of political elites. The elites, however, must take into account social moods and associated emotions.

Scientific literature on Poland's foreign policy following 1989 is large and constantly growing. Yet, the eponymous problem is virtually absent in it. Thus, it seems reasonable to refer to the views of the political elites of the Third Republic 
of Poland, which influenced the election appeals created for the parliament campaign, that is to say, being by definition the response to the needs of the electorate. Foreign policy and security issues were part of the canon of the electoral declarations, but they were often enriched with more pressing issues in the field (Skrabacz, 2013). The aim was to win voters for a particular vision and related activities. Thus, the subject of research shall be the analysis of political discourse which includes the official statements or program documents formulated by the positionally defined political elites, including electoral programs.

In this brief overview I will try to prove the local, or at best the regional, European dimension of Polish geopolitical codes and their dependence on the strong states of the West, mainly the USA. In examining the title geopolitical codes I shall largely refer to Colin Flint's systematics, focusing more on the codes of allies than the enemies of Poland; bearing in mind, however, that the problem is too broad and difficult to present in such a short presentation.

\section{CRITICAL GEOPOLITICS}

In contemporary geopolitics an increasingly important role is played by the critical approach, little known in Poland, which is, however, rather difficult to define. Its rather distinctive features are worth noticing: the opposition to the positivist vision of the world and science, which also means that social sciences and humanities are not devoid of values and neutral. On the contrary: any knowledge reflects the interests of the observer-researcher and is influenced by certain ideas, interests, groups, parties, social classes, nations and states.

It is then important to critical geopolitics to present the cultural context of the emergence of the theory, and above all, the value system and views of those dealing with international relations or geopolitics. Geopolitical theories are not the scientific analysis of the relationship of politics with the space, but constitute pluralistic shifts, ideas, images, embodied in the discourse created and propagated by a particular person or group of people, mostly from the power circles. Geopolitics is a way of seeing the world (in this case, the space) by the elites of a given state or nation (Potulski, 2010).

As a basis for research it applies "the top to bottom" model, creating geopolitical imaginations by elites to achieve specific benefits. It should be borne in mind, however, that there is no one-way communication, as the geopolitical images of society must also influence their formation by the elites. Geopolitics 
is seen as practical discourse describing the international situation in a spatial approach, in terms of its own, striving to justify such actions, identifying threats and choosing allies and enemies. In other words, critical geopolitics tries to study how politicians try to shape the world through their statements and actions (Macała, 2015).

\section{GEOPOLITICAL CODES}

The term was first used in 1982 by John L. Gaddis, the well-known American historian of international relations, as a notion describing the values and interests of American political elites during the rivalry with the USSR for supremacy. The concept was adopted by numerous historians, political scientists, specialists on international relationships, political geographers investigating the geopolitical codes of each country, though often in a broader and different sense than Gaddis suggested.

For our research purposes, it seems very important to take into account the concretization of geopolitical codes by the eminent political geographer Colin Flint. In his assessment, the understanding of the geopolitical code allows one to clarify a lot of international activities by analyzing the binding discourse. Thus, the way of imaging reality by the elites of power and the ability to impose their ideological interpretation on the public opinion at a national scale, but also on other states. This applies both to the superpowers as well as, to an even greater extent, to weaker states, where the global or regional hegemon is able to impose its own geopolitical code.

Each country has its original geopolitical code based on five main assumptions:

1. Who are our current and potential allies?

2. Who are our current and potential enemies?

3. How can we maintain our allies and nurture potential allies?

4. How can we counter our current enemies and emerging threats?

5. How do we justify the four calculations above to our public, and to the global community? (Flint, 2008).

Geopolitical codes are dynamic, they set a certain range of possibilities for foreign policy, depending on strength, territory, location, capabilities, aspirations, interests and influences of individual nations, and perhaps more on the identity specificity, establishment and scope of their culture. Hence their three 
basic levels: local, regional, and global. They are, however, usually intertwined to some extent. The local level of the codes is limited in principle to the impact on neighboring countries, the regional level involves countries that aspire to influence, not only the immediate neighbors. Those in power look for maps of such geopolitical codes that will allow it. In the end, some states are able to do global politics when those ruling them impose codes enabling them to influence the world order. These codes are more or less respected by other states (Flint, 2008).

\section{RETURN TO EUROPE}

The fundamental direction in the discourse of Polish elites is a strategic turn towards Western alliances, signed over the years with the abused metaphor of "return to Europe", the return to the center, the break with "the eastern mentality" and the periphery. As an antidote to the threat of loss of barely achieved independence, with a clear negative figure of a "buffer state", "located in the precarious intermediate zone" between Russia and Germany. Since in the general opinion the greatest threat to our sovereignty and security was unpredictable Russia, and Poland was too weak, the choice of allies was not particularly large (Słodkowska, 2001a; Zięba, 2012).

The elites treated the West victorious in the Cold War in the convention of "soft power" as a magnet drawing with its strength and attractiveness (Horolets, 2006). This also affected the local and regional reach of our geopolitical codes, adequate to the capabilities and interests of Poland. It is no accident that the course of the West was symbolized by the antagonistic semantic statements: freedom, democracy, peace, prosperity, contrasted with the People's Republic of Poland's period: enslavement, totalitarianism, poverty and backwardness. The alliance with the West was justified in several ways, for example, by common cultural heritage, especially the Christian one, shared history and/or the liberaldemocratic values of the European culture. This, combined with the popular sympathy, but also the West's complex in our society, legitimized the choice of the elite and facilitated the acceptance of relatively non-partner political and economic allies in our country (Słodkowska, 2001a; Słodkowska, 2001b; Horolets, 2006). 


\section{STRATEGIC ALLY}

To seek a guarantee of Poland's security and independence, it was crucial to build a lasting alliance with the only hyperpower after 1991, the symbol of freedom, power, security and prosperity (Słodkowska, 2001a). The Program of Freedom Union (1997), formulated in the era of a concrete road to entry into NATO, declared that an alliance with a global power was a condition of Poland's security, necessitating the need to give unilateral privilege to the United States (Słodkowska, Dołbakowska, 2004). The problem was that our elites did almost everything the Americans wanted for the sake of maintaining the alliance. On the other hand, the other party saw the relations with Poland through the global scale of their interests, treating it as a subordinate vassal. This asymmetry of potentials and the disproportionate Polish-American relations were expressed by words from the Civic Platform Program (Słodkowska, 2002), that is, after the accession to NATO: "in our relations with the United States we try to present a policy based on the principle of reciprocity".

The vassalization of Poland in her relations with the United States reached its climax during the presidency of George Bush junior. Its symptom was the uncritical acceptance of the American hegemonic code of the global "war on terror" by our elites. To reduce the threat and strengthen the alliance with the Americans, Poland participated in the wars in Iraq and Afghanistan (Zięba, 2012).

The visible example of the subordinate treatment of Poland by the USA was our small benefits from participating in these wars, which translated into less and less pro-American social sentiment. Hence in 2005, the Self-Defence (Samoobrona) and the Polish Peasant Party (Polskie Stronnictwo Ludowe) negatively evaluated the full acceptance of the US geopolitical code of "war on terror". The US did not follow the established rules of the world order, and their support jeopardized Polish-American friendship (The Self-Defence Electoral Program, 2005; Electoral Declaration of the Polish Peasant Party, 2005). At the same time, in the opinion of the PPP's adherents, succumbing to Washington's policy undermined our position in the EU (Electoral Declaration of the Polish Peasant Party, 2005; Gardziel, Gawroński, 2008). Following this trait, the Civic Platform argued that "Europe, and in particular the European Union, should be the focus of the foreign policy of the Republic of Poland" (A Better Life. For Everyone. The Electoral Program of the Civic Platform, 2007). 
The new narrative in bilateral relations was signaled by the statement that maintaining the alliance with the US "requires our sober approach and care for real benefits" ( $A$ Better Life. For Everyone. The Electoral Program of the Civic Platform, 2007; Zięba, 2012). CP thus promised that its policy towards the United States would be less submissive and generally stiffer, criticizing the servility of the Democratic Left Alliance and the Law and Justice. It was symbolic when Donald Tusk's government withdrew the Polish troops from Iraq and its skepticism towards the anti-missile shield.

\section{THE STRONGEST DEFENCE ALLIANCE}

NATO, as the most powerful military alliance in the world and the foothold of Western freedom and democracy in Europe, was to be the chief security guard of our country in the codes of Polish political elites (Słodkowska, 2001b). Thus, in the electoral programs of the post-Solidarity movements and in state politics since the early 1990s, Poland's security and internal stability were linked to NATO accession and to such guarantees as were enjoyed by the West during the Cold War. This was clearly demonstrated by the program of the Freedom Union striving for "full integration of Poland with the democratic countries' security structures", that is, mainly with NATO (Słodkowska, Dołbakowska, 2004; Skubiszewski, 1999). The primary goal of the accession was to weaken the threat from the East, i.e., protecting Poland against Russia's imperialistic policy, the greatest opponent of our presence in the Treaty. It also justified the postulate of broadening the Alliance's reach to our neighbors from the region to strengthen their sovereignty and security against the growing threat of Russia (Słodkowska, Dołbakowska, 2004; Kuźniar, 2008). In the discourse of electoral programs, there were often statements about the quality of our membership in NATO, and therefore our guarantee of security. The postulate of the Solidarity Electoral Action (Akcja Wyborcza Solidarność) applying for "full” membership can be treated in such a way (Słodkowska, Dołbakowska, 2004).

Still, most of our elites saw the price for this in the form of submission to the hegemonic position of the United States, as it was Washington that made the final decisions in the Alliance. It should suffice to mention our acceptance of NATO's transformation into a global alliance, such as support for out of area operations, primarily within the US interest. The symbol in the discourse may be words from the program of the Civic Platform: the Alliance "should be ready 
to conduct peacekeeping operations and combat asymmetric threats, including terrorist ones" (A Better Life. For Everyone. The Electoral Program of the Civic Platform, 2007). It was not determined, however, which and where, that is, the American indications were to be followed.

However, even the Iraqi and Afghan conflicts have shown many of NATO's internal weaknesses, with growing discrepancies within the EU. Hence the fears of the effectiveness of the support of Poland's security only on the external foundations, which forced the submission to allies. As one of the few parties L\&J noticed this problem: "the events from the recent years have shown that sheer NATO and the European Union membership does not guarantee full security" (Modern-United-Safe Poland. The Law and Justice Program, 2009). Each country has to take primary care of its own security, which for many years was misunderstood not only by the majority of the elites, but also by the society convinced that the international prosperity of Poland would last forever.

\section{DEEPENING INTEGRATION OR EUROPE OF HOMELANDS?}

The majority of Polish political elites supported Poland's accession to the European Union. Still, even the foundations of this road and the vision of Europe we were to enter were different. They were more concerned with the sphere of values, e.g., respect for "national interests and traditions" (Słodkowska, 2001b; Słodkowska, Dołbakowska, 2004), especially in the field of protection of our Christian identity and sovereignty. Hence the Solidarity Electoral Action, whose representatives were in power in 1997-2001 and conducted accession negotiations, treated the integration with the EU with caution. It was expressed in the words that the "dangerous visions of «Europe devoid of values» should be rejected as a threat to the return of totalitarianism and narrowing politics down only to a game of businesses in which victory is secured to the rich and powerful - no matter who is right" (Słodkowska, 2002). That is why many right-wing and people's circles continually used the slogan of the creation of the "Europe of homelands", i.e., the protection of the identity and subjectivity of nations on the grounds of equality (Słodkowska, Dołbakowska, 2004; Słodkowska, 2002). A strong state was supposed to facilitate the defence of Polish interests. On the one hand, the postulate of equality in relation to the "old Union" countries pointed to serious concerns about the subordinate role of Poland, and was followed by a disagreement to "deeper integration". Undoubtedly, the protection 
of the sovereignty and the subjectivity of nations was generally in conflict with this process.

On the other hand, it was the Union that set the conditions, not the aspiring state. Hence, in the discourse layer for the Eurosceptic part of the representatives of political elites, the aim of "integration" with the EEC/EU should be on the "partnership" basis rather than "too submissive" because it meant accepting unfavorable solutions for Poland. The idea was supported by an antagonistic division into the "old" and the "new" Europe: the old EU being a selfish "rich club" discriminating against its poor cousins from the East, although the essence of the Union should be the mythical word "solidarity" (Słodkowska, 2001b; Modern-United-Safe Poland. The Law and Justice Program, 2009; Horolets, 2006).

Part of the elites, the so called Euro-enthusiasts, emphasized the real incompatibility of integration in their geopolitical codes. We had to strive for accession, because only the accession to the EU served the development of the whole country and all social groups, it became an opportunity to catch up with the civilization delay of Poland and increase its role in Europe. So the offer for voters was unequivocal: if you want to be safe and rich as the West, you should agree even to the difficult and unfavorable entry conditions that the EU stipulated. After all, "only through the European Union are we able to achieve the standard of living of European countries" - the context was clear that it was all about the so-called old members of the EU (Electoral Manifesto of the Democratic Left Alliance, 2005).

Using high levels of public support for Poland's presence in the EU, many of those circles following the accession used in their discourse the transactional phrase "deepening integration". For example, the Democratic Left Alliance assessed that "Poland's best interests are to deepen and broaden integration within the European Union" (Tomorrow for Poland. A Program for Poland. The Democratic Left Alliance, 2011). This could be seen as a vague acceptance of the gradual federalization of the Union. As Poland was too weak in the Union, apart from admitting new members, it was in her interests to institutionalize empowerment of EU bodies and the Euro area at the expense of the powers and sovereignty of the Member States (Gardziel, Gawroński, 2008). It was believed that "Brussels would defend us" against the unfavorable attempts against Polish position and modernization to create a "double-speed Europe' and to strengthen the national egoisms (Tomorrow Without Fear. A Program for Poland. The Democratic Left Alliance, 2011). 


\section{GERMANY - OUR ADVOCATE OR MASKED ENEMY?}

In the electoral discourse of the first years of transformation, the fear of the power of united Germany as a threat to our sovereignty and territorial integrity was clearly visible. It was relatively easy to fuel such emotions among voters. Reasons: first and foremost, a difficult history, and with it, the negative stereotypes and phobias, and a large disproportion of potentials, especially in the economic sense. Finally, the ambiguity of German policy in the years 1989-1991 (Słodkowska, 2001a; Zięba, 2012).

However, when the elites had embarked on their strategic Euro-Atlantic course, they realized that, metaphorically, "the shortest route to Europe" is through Germany. Hence, in the discourse, the restraint of animosity was recommended first, and later the development of such relations that Germany would become a desirable "advocate" of our integration with the West, which assumed the "advocate-client" relationship. On this basis our elites tried to find a "community of interests" in security, politics and economics with the FRG, which to a large extent enabled Poland to join NATO and the EU. However, the hopes of breaking the difficult past, the historic reconciliation, as in the German-French model, turned out to be futile. Despite successes in the field of political and economic relations, the historical disputes have not ceased (Zięba, 2012).

A new wave of fears of Germany in electoral programs emerged with Poland's accession to the EU, when her declared "community of interests" weakened and divergences and disagreements arose, for example against Poland's involvement in the Iraq war. Gradually, however, they subsided, and the discourse of major political forces again adopted the words "partnership", "community of interests", "close cooperation". In the programs of the most prominent political parties during the period of the Civic Platform-Polish Peasant Party coalition, the need to maintain good relations with Germany was not questioned, despite differences of opinion, as it was in our interest. For some, especially those in power, they justified Berlin's patronage over Warsaw. For others, it was too high a price, as symbolized by the 2011 Law and Justice criticism of "client attitude" attributed to the CP-PPP government. Jarosław Kaczyński’s party demanded that mutual relations should be developed on a partnership basis, based on "the principles of subjectivity, equality and symmetry of both parties" (Modern-United-Safe Poland. The Law and Justice Program, 2009). 


\section{NEVER UNDERESTIMATE THE STRENGTH OF RUSSIA}

When analyzing the discourse of electoral programs, one can conclude that the constantly identified enemy of Poland, although not named directly, has been Russia. This geopolitical code of our elites was supported by most Poles, and the scale and justification of mutual animosity were relatively simple and legible. To all, the key to the security and independence of Poland and the regaining of freedom in the choice of allies was to become free from "the effects of many years of military, economic and political dependence on the Soviet Union" (Słodkowska, 2001a; Zięba, 2012).

Russia was generally regarded as the successor of the USSR, which negatively affected the geopolitical environment of our country. It was expressed in the multi-level imperial policy. Right-wing electoral programs signaled it in the statement that the Kremlin cannot put up with the loss of its satellite states and still continues its Poland-threatening policy (Słodkowska, Dołbakowska, 2004). The second plane of Russia's hostile actions is a possible internal disintegration, though rarely raised. In this direction, the discourse of the Law and Justice was particularly directed, warning of the consequences of "having many of our partner's assets within our country”, i.e., intelligence (Słodkowska, 2002). The fear of Russia was also stimulated in another way, dramatizing its internal chaos and the instability of state structures, the importation of pathologies such as crime and illicit trade (Słodkowska, 2001a; Słodkowska, Dołbakowska, 2004).

Because the electoral discourse repeatedly warned, "we must not underestimate the power of Russia" (Słodkowska, Dołbakowska, 2004), it justified the return to the West in the $1990^{\text {s }}$ to find allies there to ensure Poland's sovereignty and security. Undoubtedly, Poland's entry into the Western political-military and economic security structures has strengthened our state's position in relations with Russia but has not improved them. Polish elites understood the need to reduce tension and develop cooperation. In 2007, the Civic Platform suggested a pragmatic approach, developing our mutual relations "on interestedness, getting rid of unnecessary emotions and empty gestures", or "rejection of history fatalism", at the same time perceiving "unfriendly accents and unconquerable complexes" in Russian politics (A Better Life. For Everyone. The Electoral Program of the Civic Platform, 2007). A more optimistic narrative about Polish-Russian relations emerged after the Smolensk catastrophe, which was supposed to be a tragic, yet a chance to overcome mutual reluctance. It appeared in the Civic Platform program, in sync with the narrative of the Democratic Left Alliance. 
The Alliance believed in 2011 that "there is a historic opportunity to develop a new formula of Polish-Russian cooperation" (Tomorrow Without Fear. A Program for Poland. The Democratic Left Alliance, 2011).

It was perceived quite differently by the Law and Justice in 2011, in the shadow of the Smolensk disaster, with the party frightening voters that the policy towards Russia by the government of Donald Tusk was of "deep asymmetry and completely unilateral concessions, not only without reciprocity but even without expecting it" (Modern-United-Safe Poland. The Law and Justice Program, 2009). It defined the degradation of Poland's status in relations with Russia. In other words, the CP-PPP government was accused of conducting pro-Russian politics, and L\&J in 2005-2007 allegedly maintained Poland's subject status in these relations.

\section{OUTSIDE THE EUROPEAN UNION}

Much less readable for most elites and citizens was the hostility to the European Union, which was demonstrated by some nationalist milieu, presenting the Community in black colors as a threat to our identity and sovereignty. The categorical opposition to Poland's integration with the European Union appeared in the discourse of these circles: it is the enemy that will rule us with the "dictate of Brussels", as did the dictate of Moscow previously. Such a change of polarity of political dependence appealed to civil emotions and the fears of repetition of Poland's servile status. Thus, the integration with the EU was dramatized as an external dependence of power, implementing foreign interests in our country, leading to economic and political disaster. No nation should allow "the unilateralism of the economic and political dependencies of its State" (Słodkowska, 2002).

The EU enemy was perceived somewhat differently in the EU by the SelfDefence, formally advocating Poland's entry into the Community. Already after its accession in 2005, it argued that the conditions negotiated by Poland were "second class" membership, that is to say, the confirmation of our subordinate status of "worse Europe", leading, according to the rare in our discourse argumentation, to "colonial dependence of Poland on international economic and political organizations". The Self-Defence confirmed at the same time its antiestablishment image, arguing that it was possible to negotiate better accession conditions, but it was not wanted by the group of Polish elites, servile to the 
West. For "betrayal and servitude to foreign interests, they will receive the due reward from the hands of their lords" (The Self-Defense Electoral Program, 2005). In other words, the "Targowica" - the commonly perceived negative symbol of treason and exploitation by foreign interests - among our elites was to be blamed for the poor and humiliating conditions of Poland's integration with the Union.

\section{SUMMARY}

Undoubtedly, the title issue was not one of the most important ones in the electoral programs of the political parties, and the way of its presentation disappoints with its fragmentary and generalized approach. In general, the fundamental change of Poland's geopolitical codes after 1989 - from the east to the west can quite easily be seen in the electoral programs: the enemies of the People's Republic of Poland became allies and the forced ally became an enemy. However, their concretization is generally not original and rather schematic. The Polish geopolitical codes have been exerted with strong influences of the hegemonic geopolitical codes of the West, mainly those of the United States. On the other hand, the last geopolitical code, the attempt to explain to the public the geopolitical imaginations of our elites, has been the weakest. This largely confirms the authoritarian dimension of Polish transformation as well as the dominance of the elites over the society.

\section{REFERENCES:}

A Better Life. For Everyone. The Electoral Program of the Civic Platform. (2007). Retrieved from: https://mamprawowiedziec.pl/file/14512.

Electoral Manifesto of the Democratic Left Alliance. (2005). Retrieved from: http://www. sld.org.pl/public/ckfinder/userfiles/files.

Electoral Programme of the League of Polish Families. (2005). Retrieved from: http:// mizerski.com/2007/programwyborczy-lpr-w-wyborach-2005/.

Flint, C. (2008). Wstęp do geopolityki. Warszawa: Wydawnictwo Naukowe PWN.

Gardziel, T., Gawroński, S. (2008). Wybory 2007. Partie, programy, kampania wyborcza. Rzeszów: Wyższa Szkoła Informatyki i Zarządzania w Rzeszowie.

Horolets, A. (2006). Obrazy Europy w polskim dyskursie publicznym. Kraków: Universitas.

Kuźniar, R. (2008). Droga do wolności. Polityka zagraniczna III Rzeczypospolitej. Warszawa: Wydawnictwo Naukowe Scholar. 
Macała, J. (2015). Kody geopolityczne jako element analizy dyskursu w myśli politycznej. In: E. Maj, E. Kirwiel, E. Podgajna (eds.), Myśl polityczna w społeczeństwie informacyjnym (p. 105-120). Lublin: Wydawnictwo Uniwersytetu Marii CurieSkłodowskiej.

Modern-United-Safe Poland. The Law and Justice Program. (2009). Cracow: Law and Justice.

Potulski, J. (2010). Wprowadzenie do geopolityki. Gdańsk: Wydawnictwo Uniwersytetu Gdańskiego.

The Self-Defense Electoral Program. (2005). Retrieved from: http://mizerski.com.pl/ program-wyborczy-samoobrony-w-wyborach-2005.

Skrabacz, E. (2013). Słowa, słowa, słowa - dokumenty programowe polskich partii politycznych. In: M. Wincławska (ed.), Partie polityczne w poczatkach XXI wieku. Problemy rozwoju, organizacji i funkcjonowania (p. 133-156). Toruń: Wydawnictwo Naukowe Uniwersytetu Mikołaja Kopernika.

Skubiszewski, K. (1999). Polska i Sojusz Północnoatlantycki w latach 1989-1991. Sprawy Międzynarodowe, 52(1), 10-49.

Słodkowska, I. (ed.). (2001a). Wybory 1991. Programy partii i ugrupowań politycznych. Warszawa: Instytut Studiów Politycznych Polskiej Akademii Nauk.

Słodkowska, I. (ed.). (2001b). Wybory 1993. Partie i ich programy. Warszawa: Instytut Studiów Politycznych Polskiej Akademii Nauk.

Słodkowska, I. (ed.). (2002). Wybory 2001. Partie i ich programy. Warszawa: Instytut Studiów Politycznych Polskiej Akademii Nauk.

Słodkowska, I., Dołbakowska, M. (eds.). (2004). Wybory 1997. Partie i ich programy. Warszawa: Instytut Studiów Politycznych Polskiej Akademii Nauk.

The Electoral Declaration of the Polish Peasant Party. (2005). Retrieved from: http://psl. pl/upload/pdf/dokumenty/Deklaracja_wyborcza_2005.pdf.

The Next Step. Together. The Electoral Program of the Civic Platform. (2011). Retrieved from: http://www.platforma.org/media/dokumenty/Program_PO_100dpi.pdf.

Tomorrow Without Fear. A Program for Poland. The Democratic Left Alliance. (2011). Retrieved from: http://www.sld.org.pl/ckfinder/userfiles/files/program_sld.pdf.

Zięba, R. (2012). Główne kierunki polityki zagranicznej Polski po zimnej wojnie. Warszawa: Oficyna Wydawnicza Łośgraf. 